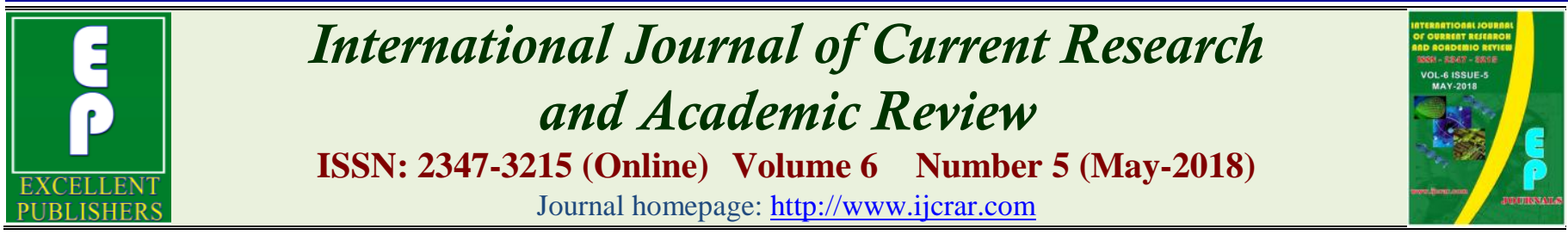

doi: https://doi.org/10.20546/ijcrar.2018.605.007

\title{
Productive and Reproductive Performance of Indigenous Ethiopian Cow under Small Household Management in Dawro Zone, Southern Ethiopia
}

\author{
Taju Hussein*
}

Department of Animal and Range Sciences, Wolaita Sodo University College of Agriculture, PO.Box 138, Wolaita

Sodo, Ethiopia

*Corresponding author

\section{Abstract}

The current survey was carried out in Dowro zone southern Ethiopia to assess productive and reproductive performance of native cow under farmer condition. Through purposive and random sampling from each agro-ecology, 90 household were interviewed. The collected data were analyzed by statistical package for social science and significant means were differentiated via LSD and Tukey HSD. The study revealed that on average native cow produced $1.8 \pm 0.045$ liters of milk per day and milk production was significantly $(\mathrm{p}<0.05)$ different between agroecologies. In addition survey result showed that in the study area on average cow is milked for $8.6 \pm 0.930$ months and lactation length is significantly $(\mathrm{p}<0.05)$ longer in highland. Beside, survey result revealed that mean age at first calving and calving intervals were $48.9 \pm 0.259$ and $16.0 \pm 0.141$ months respectively. Age at first calving significantly quick ( $46.7 \pm 0.482$ months) in lowland whereas calving interval was not varies between agro- ecologies. Furthermore, study indicated lifetime of highland cow $(12.7 \pm 0.232$ years $)$ significantly $(\mathrm{p}<0.05)$ lower as compared to life time of midland (10.0 \pm 0.860 years). Production and productivity of local cow in the study area is very low. As a result improvement of production and productivity cow is the works that need collective effort by all concerned bodies.
\end{abstract}

\section{Article Info}

Accepted: 20 April 2018

Available Online: 20 May 2018

\section{Keywords}

Calving interval;

Dawro milk yield;

Lifetime.

\section{Introduction}

The livestock sector globally is highly dynamic. In developing countries, it is evolving in response to rapidly increasing demand for livestock products. In developed countries, demand for livestock products is stagnating, while many production systems are increasing their efficiency and environmental sustainability (Philip, 2010). The livestock sector is increasingly organized in long market chains that employ at least 1.3 billion people globally and directly support the livelihoods of 600 million poor smallholder farmers in the developing world
(Thornton et al., 2006). Livestock play very important roles in food security. To get such roles from the livestock, their productivity should be optimum (ILRI, 2006). Ethiopia has the largest livestock inventories in Africa and this sector has a significant contribution to the country's economy and is still expected to support its economic development (CSA, 2013). Cattle production is one of the main agricultural industries in Ethiopia. The country produces over 3.8 billion litres of milk and $\sim 1$ million tonnes of beef per year valued at USD 2.5 billion and USD 5.1 billion, respectively (FAO,2018). 
Underlying all animal breeding studies is the fact that neither all animals nor all breeds are equal. There are different aspects of management including differences within and between breeds in production, reproduction, fertility, size, disease resistance and the ability to withstand stress (Nuraddis and Ahmed, 2017). The indigenous breeds of tropics are attributed to natural selection to the tropical environment and management. They are well known for their adaptability, hardiness, disease resistance, heat tolerance, low feed supply and low management level. To meet the ever-increasing demand for milk and milk products genetic improvement of the indigenous cattle has been proposed as one of the options (Kumar et al., 2014). However, lack of understanding of the farming systems, prevailing constraints, and prospects of possible interventions in line with the socio-economic scenarios of the farmers constitutes by itself the fundamental problem for the development of the livestock sub-sector in Ethiopia (Zinash et al,. 2001). Any intervention program should start with identification of farmers' problems and subsequently develop and test appropriate technologies under farmers' conditions (Geshaw, 1992).

Performance record of local cows is essential for designing breeding as well as manage mental strategies develop the dairy sector (Kumar et al., 2014).

In Ethiopia number of exotic and hybrid cattle is extremely low. This suggests that the total number of both exotic and hybrid female cattle produced through the crossbreeding work for many decades in the country is quite insignificant indicating unsuccessful crossbreeding work. This again suggested that Ethiopia needs to work hard on improving the work of productive and reproductive performance of cattle through appropriate breeding and related work most important factor that is a prerequisite for sustainable performance improvements of cattle through appropriate dairy production system and influencing the productivity breeding and related activities (Nuraddis and Ahmed, 2017). Therefore for better improvement of local cow, sustainability of improvement, easy and cost wise improvement, understanding of local cow production and reproductive status of local cow is first and ever needed step in animal improvement area particularly in Ethiopia which has huge livestock population but couldn't meet animal protein demand ever increasing. Thus the current survey result was conducted to generate baseline data on production and reproductive performance of local cow in Dawro zone southern Ethiopia.

\section{Materials and Methods}

\section{Description of the study area}

The study was conducted in Dawro zone, Southern Ethiopia, from September 2016 to June 2017. Dawro zone is located at a distance of $512 \mathrm{~km}$ far from Addis Ababa. The study area has an altitude ranging from 501 to 3000 meters above sea level mean annual rainfall varying between $1201 \mathrm{~mm}$ to $1800 \mathrm{~mm}$; and the mean minimum and maximum annual temperatures of 15.1 and $27.5^{\circ} \mathrm{C}$, respectively.

The study zone has five districts/woredas distributed in three agro-ecological zones; lowland or kola (55.6\%), midland or weinadega $(41.4 \%)$ and highland or Dega (3\%). Mixed crop-livestock farming system, involving the production of cereals different livestock species, is predominantly practiced (Southern regional state investment bureau, 2011).

\section{Sampling techniques and sample size}

Purposive and random sampling methods were employed for the study (Figure 1). At first stage from each of the three agro-ecologies (i.e. highland, midland and lowland) of the zone one representative district that are Mereka district from highland, Loma from midland and Gena Bosa from lowland were selected purposively based on the number and intensity of livestock production and accessibility. At second stage from each of the selected district, three representative peasant associations (PAs)/kebeles (lower administrative structure) were randomly selected. Finally, a total of 270 respondents, 90 respondents from each district, were included in the survey study.

\section{Data sources and methods of data collection}

Both primary and secondary sources of data were used for the study. To collect the primary data, a semistructured questionnaire was designed, pre-tested and then modified for appropriateness before the actual data collection was commenced. Experienced numerators was recruited and trained to facilitate this task of primary data collection under the close supervisions of the researcher. To reinforce the primary data, direct observation, group discussion with key informants and informal interview was carried. The secondary data was collected from different office of study zone, selected districts' and other relevant sources. 


\section{Data analysis}

Statistical package for social science (SPSS) version 20 was used to analyze the collected data. The difference between means was separated via LSD and Tukey HSD at $95 \%$ of confidence interval.

\section{Results and Discussion}

\section{Productive performance local cow}

\section{a. Average daily milk production}

Production performances of indigenous dawro cow under household are presented in table 1. Average daily milk production of local cows in highland $(2.2 \pm 0.083)$ and midland (2.3 \pm 0.370$)$ is significantly higher as compared to average daily milk yield of lowland cows $(1.1+0.024)$. The difference might be due to differences in feed availability particularly supplementation differences, and climate impact (temperature). In general overall milk yield of local cows in the study area was $1.8 \pm 0.045$ liters per day. The milk yield of local cows of the study districts are all most the same to local cow daily milk reported for different areas of local cattle of the country which is approximately with the range of 1.7 to 1.9 liters per day (Alganesh, 2002; Gebrekidan et al., 2012; Wondossen, 2017). On the contrary milk yield of less or equal to 1 liter per cow per day (Merha, 2006;
Mohammed et al., 2016) and higher than 2 liters per cow per day also reported in different part of the country for local Ethiopian cows (Yoseph et al., 2003; Damitie et al., 2016; Kebede et al., 207).

Mixed crop-livestock dairy production is a subsistence oriented farming system concentrated in the mid- and high-altitude agro-ecological zones where cereals and cash crops are dominant farm activities milk production is an integral part of the production system (FAO, 2018). Milk yield per cow is 1.9 liters per day on average (Dairy Policy Inventory, 2009 cited in FAO, 2018). On the other hand CSA (2017) reported that national average milk yield from local cow per day is 1.37 which is lower than current finding. A Ministry of Finance and Economic Development (MoFED) report highlights that there is a significant productivity difference among local dairy breeds. The milk yield for local dairy breeds is about 1.5 liters per day per cow, which is about one-eighth of the milk yield (9 liters per day per cow) for improved dairy breeds (Asfaw et al., 2013.). All available statistics suggest that the productivity of livestock of Ethiopia is among the lowest in the world. Ethiopia lags behind almost all regional countries, regional averages, and world averages of productivity. The most strikingly low productivity is in milk production, where Ethiopia's production of 210 kilograms per year per cow is less than a tenth of the world's productivity of 2.3 tons and about a third of Kenya's (551 kilograms) (Asfaw et al., 2013).

Table.1 Average daily milk yield and lactation length of indigenous cow in the study area

\begin{tabular}{|c|c|c|c|c|c|}
\hline Parameters & \multicolumn{3}{|c|}{ Agro- ecological zone } & \multirow{2}{*}{$\begin{array}{l}\text { Overall } \\
\text { (Mean } \pm \text { SE }\end{array}$} & \multirow[t]{2}{*}{$\mathrm{P}$ values } \\
\hline & $\begin{array}{l}\text { Lowland *(Mean } \\
\pm \mathrm{SE})\end{array}$ & $\begin{array}{l}\text { Midland *(Mean } \\
\pm \text { SE })\end{array}$ & $\begin{array}{l}\text { Highland*(Mean } \\
\pm \mathrm{SE})\end{array}$ & & \\
\hline AVM (liter) & $87\left(2.2 \pm 0.083^{\mathrm{a})}\right.$ & $85(2.3 \pm 0.037) 0^{\mathrm{a}}$ & $90\left(1.1+0.024^{\mathrm{b}}\right)$ & $1.8 \pm 0.045$ & 0.000 \\
\hline LL (month) & $89\left(10.0 \pm 0.105^{\mathrm{a}}\right)$ & $87\left(8.7 \pm 0.060^{b}\right)$ & $86\left(7.0 \pm 0.085^{c}\right)$ & $8.6 \pm 0.930$ & 0.000 \\
\hline
\end{tabular}

a,b,c,; Means within a row with different superscripts differ significantly $(\mathrm{P}<0.05)$. ${ }^{*}=$ number of respondents; $\mathrm{AFC}=$ average at first calving; $\mathrm{CI}$ calving interval; $\mathrm{NA}=$ not available; $\mathrm{SE}=$ standard error

Table.2 Age at first calving, calving interval and lifetime of indigenous cow in the study area

\begin{tabular}{|c|c|c|c|c|c|}
\hline Parameters & Agro- ecological z & & & Overall & $P$ values \\
\hline & $\begin{array}{l}\text { Lowland } *(\text { Mean } \\
\pm \mathrm{SE})\end{array}$ & $\begin{array}{l}\text { Midland *(Mean } \\
\pm \mathrm{SE})\end{array}$ & $\begin{array}{l}\text { Highland*(Mean } \\
\pm \text { SE) }\end{array}$ & (Mean $\pm \mathrm{SE}$ & \\
\hline AFC(month) & $87\left(51.0 \pm 0.458^{\mathrm{a})}\right.$ & $86\left(49.3 \pm 0.222^{b)}\right.$ & $90\left(46.7 \pm 0.482^{\mathrm{c})}\right.$ & $48.9 \pm 0.259$ & 0.000 \\
\hline $\mathrm{CI}$ (month) & $86(16.5 \pm 0.140)$ & $87(16.0 \pm 0.211)$ & $90(15.7 \pm 0.112)$ & $16.0 \pm 0.141$ & 0.116 \\
\hline $\begin{array}{l}\text { Longevity } \\
\text { (year) }\end{array}$ & $87(12.7 \pm 0.232)^{\mathrm{a}}$ & $86(10.0 \pm 0.860)^{b}$ & NA & $11.4 \pm 0.181$ & 0.000 \\
\hline
\end{tabular}

a,b,c,; Means within a row with different superscripts differ significantly $(\mathrm{P}<0.05) .{ }^{*}=$ number of respondents; $\mathrm{AFC}=$ average at first calving; $\mathrm{CI}$ calving interval; $\mathrm{NA}=$ not available; $\mathrm{SE}=$ standard error 
Figure.1 Sampling technique and sample size of the study

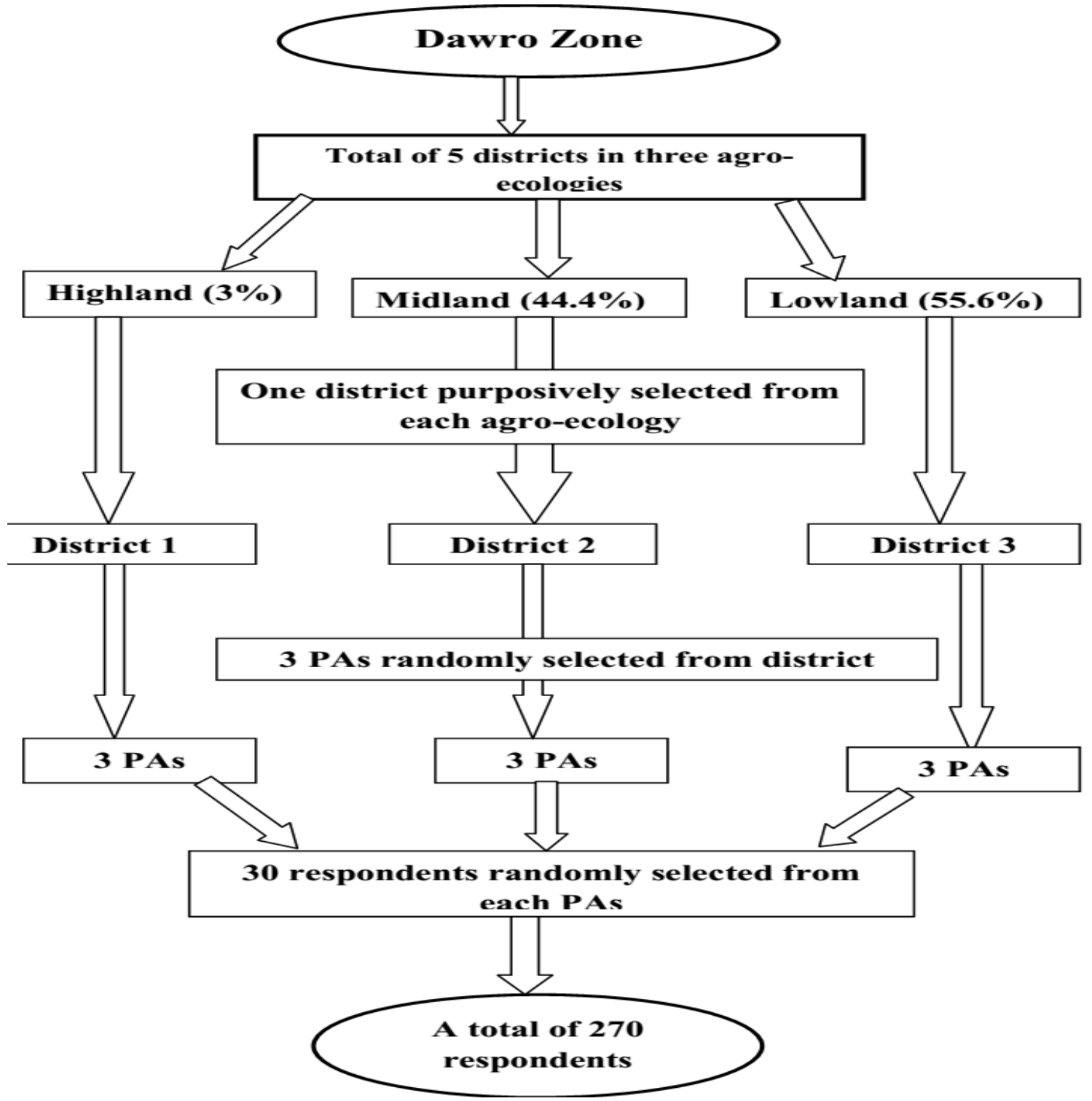

\section{Lactation length}

Not only daily milk produced, lactation length is also one of factors that determine profitability of a given dairy cows owning individuals and productivity of a dairy cows as well. Most of the time Ethiopian dairy cow known by short period of lactation and long calving interval which shows that animal is being kept for long period of time without giving any products (milk and calf) and simply took feed and other cost of production. As can be seen from the table 1, lactation length of local dairy cows is significantly differ $(\mathrm{P}<0.05)$ among agroecology, lactation length is significantly longest in highland area $(10.0 \pm 0.105)$ relative to midland $(8.7 \pm 0.060)$ and lowland $(7.0 \pm 0.085)$. Highest lactation length in highland might be due to availability of feed and water and less impact of temperature. In the current study districts and overall mean lactation length is about $8.6 \pm 0.930$ months. The current observed lactation length is comparable with previous finding of Belay et al., (2012) and Kumar et al., (2014) who reported mean lactation length of 255.75 and $247.11 \pm 22.64$ days respectively for local Ethiopian milking cows. Whereas the current lactation length local cows is higher by two months as compared to CSA (2017) who reported that average lactation period per cow during the reference period at country level about six months. But lower than the report of lactation length reported by Lemma et al., (2005), Mulgeta and Belayneh (2013), Zeru and Lijalem (2016) who reported mean lactation length of 9.5, 
$9.13 \pm 2.63$ and $10.80+0.053$ months for native cattle in/ around Bahirdar, North shoa zone, Amahara region, East shoaw zone, Oromia region, Wolaita zones Southern region respectively.

\section{Reproductive performance local cow}

\section{Age at first calving (AFC)}

Age at first calving is one of reproductive performances which measures the age at which the heifer success fully delivery its first offspring. It is economical important traits that can help to estimate productive and reproductive performance of a given animal in its future live. AFC of current study area is shown in table 2. As shown in the table, local cows delivered its first calf at the age of $51.0 \pm 0.158,49.3 \pm 0.222$ and $46.7 \pm 0.482$ months in highland, midland and lowland respectively and the overall AFC was $48.9 \pm 0.259$ months or approximately 4 years. Moreover, AFC was significantly different across ecology with significantly shorter AFC in lowlands followed by midland and highland which might be due to higher temperature which might be initiate quickly age at first heat in lowland and midland relative to highland. Overall mean AFC of local cattle of the zone is close to the mean of AFC of Begayet cattle (48.8 months) Mulugeta (2015) and Chacha area cattle North Show zone (47.16 \pm 8.7 months) Mulgeta and Belayneah (2013) and shorter than mean of AFC reported by Kebede et al., (2017), Dessalegn et al., (2012), Endashaw and Tadelle (2015) who reported that $4.7 \pm 1.31,4.98 \pm 0.68$ and 4.6 years for Gofa cattle, cattle in Benchi-Maji zone and Mursi cattle respectively. On the other hand Rege et al., (2006) reported AFC of 60, 53.4 and 53 months for Begeit, Fogera and Horro breed respectively which is longer than current report.

\section{Calving interval (CI)}

Mean (mean + SE) calving interval of native cows of Dawro cows in different agro-ecology presented in table 2. The mean $\mathrm{CI}$ is statistically insignificant $(\mathrm{P}>0.05)$ between agro-ecological zone, but figuratively the mean CI of highland $(15.7 \pm 0.112)$ seems lower in relative to midland (16.0 \pm 0.211$)$ and lowland (16.5 \pm 0.140$)$. Overall average CI $(16.0 \pm 0.141)$ local cattle obtained in the present study longer than the previous CI reported by Kumar et al., (2014), Deselagn (2016), and Gebratansae(2017) who reported that CI of $431.08 \pm 78.3$ days, $13.8 \pm 9$ months, 14.82 and 12.03 months for local cattle around Mekele Tigray regional state, crossbred in Bishoftu area and cattle in highland of Bure districts oromia regional state and begaite cattle Amhara regional state, managed under small and large scale respectively. On the other hand CI higher than current study 54.1months Dejane (2014), 54.1 months, Teketle (2005) 54.7 Zewde(2004), 26.6 \pm 06 and 18.72 \pm 0.5 months Ayanesh et al.(2018)for Kerrayu, Sheko, Wegera, and cattle around Gonder area respectively was reportd. CI varies due to age of cows, breed of cows, calving season and forage availability in any particular year (Yifat et al., 2012).

\section{Lifetime of local dairy cows}

Lifetime local dairy cows were presented in Table (2). As shown in table all of households found in lowlands in current study did not responded to lifetime of dairy cows thus the data shows only life time of highland and mid land of local cows. The mean lifetime of local cows in midland and highland is $10.0 \pm 0.186$ and $12.7 \pm 0.232$ yeas respectively. The overall mean lifetime of the local cow in these agro-ecologies is $11.4 \pm 0.181$ years and statistically significant $(\mathrm{P}<0.05)$ between midland and highland, local cows in highland have long lifetime as compared to midlands. The cool environment of highland, availability feed, management variation might be among factors contributed highland cows to have long lifetime. Overall mean lifetime of native cattle of the current study area is similar with mean lifetime report of Kefene (2015) who reported life time of $4200 \pm 135$.1 and 4269.8 \pm 135.1 days for first cross of Holstein Frisian and Boran and Jersey and boran respectively in highland of holleta. Similarly Dejene (2015) reported that 11.5yeras of lifetime for Bakko native cattle. Heard life productivity of Ethiopian indigenous cattle is 11 to 13 years (Mukasa-Mugerwa et al., 1989).

\section{Conclusion and Recommendation}

Productive and reproductive performances are the most important traits in animal production for economic benefit of producers and now a day it is worry of many countries with special emphasis in developing countries like Ethiopia. From current survey results it can be concluded that both productive and reproductive performance of local cow of the study area is very low and lag at the back of many African countries local cow productivity. The same to other part of the country, local cow (dawro cow) in the current study are characterized by low daily milk yield, long calving interval and long time taken to reach age at first calving or longer age of puberty in short. But, on the contrary daily milk need of the country's population and price of one liter of milk is 
increasing dramatically every day. Therefore, as matter of fact improvement of production and productivity of local cow by any means of improvement to meet dramatically increasing need of milk yield and to cut off price of milk in order to make affordable cost by all classes of country's population is unquestionable agenda and the work that need collective effort by household, government and other concerned bodies too.

\section{References}

Alganesh T.2002. Traditional milk and milk products handling practices and raw milk quality in Eastern Wollega. M.Sc. Thesis

Asfaw Negassa, Shahidur Rashid, Berhanu Gebremedhin, and Adam Kennedy 2013

Ayeneshet B, Abera M and Wondifraw Z. 2018. Reproductive and Productive Performance of Indigenous Dairy Cows under Smallholder Farmers Management System in North. Journal of Fisheries and Livestock Production.6(1):1-5.

Belay Duguma and Geert Paul (2012). Assessment of feed resources, feeding practices and coping strategies to feed scarcity by smallholder urban dairy producers in Jimma town, Ethiopia. Springer Plus. Pp. 1-12.

Central Statistical Agency of Ethiopia (CSA). 2017. Agricultural Sample Survey. Volume II: Report Livestock and livestock characteristics (Private peasant holdings). Statistical Bulletin 570. Central Statistical Agency (CSA), Federal Democratic Republic of Ethiopia, Addis Ababa April 2017

Central Statistical Agency of Ethiopia (CSA). 2017. Agricultural sample survey. Report on livestock and livestock characteristics. The Federal an nDemocratic republic of Ethiopia, Central Statistical Agency (CSA). Private Peasant Holdings. Statistical Bulletin 570, Addis Ababa, Ethiopia, April, 2013.

Damitie Kebede, Kefyalew Alemayehu and Endalkachew Girma. 2016. Reproductive and Productive Performance of Fogera Cattle in Lake Tana Watershed, North Western Amhara, Ethiopia. Journal of Reproduction and Infertility 6 (2): 56-62.

Dejene Takele.2014. Assessment of Dairy Cattle Husbandry and Breeding Management Practices Lowland and Mid-Highland Agro-Ecologies Borana Zone. Animal and Veterinary Sciences, 2(3): 62-69. doi: 10.11648/j.avs.20140203.12

Dereje Bekele.2015. On Farm Phenotypic Characterization of Indigenous Cattle and Their Production Systems in Bako Tibe and Gobu Sayo
Districts of Oromia Region, Ethiopia.M.Sc Thesis. Haramaya University, Haramaya

Endashaw Assefa.2007. Assessment on production system and marketing of goats at Dale district, Sidama Zone. An MSc Thesis, Hawassa University, Ethiopia

FAO. 2018. Africa sustainable livestock 20150: Livestock production systems spotlight Cattle sectors in Ethiopia. Pp1-11. FAO, 2018I8271EN/1/01.18

Gashaw Geda. 1992. Assessment of Feed Resources Base and Performance of Crossbred Dairy Cows Distributed to Smallholder in the Selale Dairy Development Project Area. M.Sc Thesis Alemaya University of Agriculture. Alemaya, Ethiopia. pp. 171

Gebrekidan T, Zeleke M and Gangwar SK.2012. Reproductive and Productive Performance of Dairy Cattle in Central Zone of Tigray, Northern Ethiopia. I. J.A.B.R. 2(1): 58-63.

Gebretnsae Mezgebe, Solomon Gizaw, Mengistu Urge and Arvind Chavhan.2017. Begait cattle production systems and production performances in northern Ethiopia. Int. J. of Life Sciences. 5 (4): 506-516.

Kebede H, Jimma A, Getiso A and Zelke B.2017. Characterization of Gofa Cattle Population, Production System, Production and Reproduction Performance in Southern Ethiopia Journal of Fisheries \& Livestock Production. 5(3):1-12.

Kefena Effa , Diriba Hunde, Molla Shumiye and Roman H. Silasie. 2013. Analysis of longevity traits and lifetime productivity of crossbred dairy cows in the Tropical Highlands of Ethiopia. Journal of cell and animal biology.7(11):138-143.

Kumar, Nirar, Yemane Abadi, Berihu Gebrekidan and Yohannes Hagos Woldearegay.2014. Productive and Reproductive Performance of Local Cows under Farmer's Management in and around Mekelle, Ethiopia. IOSR Journal of Agriculture and Veterinary Science (IOSR-JAVS) e-ISSN: 23192380, p-ISSN: 2319-2372. www.iosrjournals.org

Lemma Fita, Fikadu Beyene and Hegede B.2005. Rural smallholders Milk and dairyproducts production, utilization and Marketing systems in East Shoa Zone of Oromia. In: Proceedings of the 12th Annual conference of the Ethiopian Society of Animal Production (ESAP) held in Addis Ababa, Ethiopia, August 12-14, 2004. ESAP, Addis Ababa, Ethiopia. pp29-37.

Mohammed Husen, Yisehak Kechero and Meseret Molla. 2016. Assessment of Livestock Feed Resources Utilization in Jimma Zone, Southwest 
Ethiopia. Academic Journal of Nutrition. 5 (1): 01 17.

Mukasa-Mugerewa, E. 1989. A review of reproductive performance of female Bos indicus (Zebu) cattle, International Livestock Centre for Africa (ILCA), monograph, Addis Ababa, Ethiopia.

Mulugeta A and Belayeneh A. 2013. Reproductive and lactation performances of dairy cows in Chacha Town and nearby selected kebeles, North Shoa Zone, Amhara Region, Ethiopia. World J. Agri. 1 Sci. 1(1): 008-017.

Mulugeta, FBT. 2015 Phenotypic Characterization of Indigenous Cattle in Western Tigray, Northern Ethiopia

Mulugeta, A. 2005. Characterization of dairy production systems of Yerer watershed Adalibeb woreda, Oromia region, Ethiopia. MSc Thesis. Dire-Dawa, Ethiopia.

Philip K. Thornton, 2010. Livestock production: recent trends, future prospects, Review. Phil. Trans. R. Soc. B (2010) 365, 2853-2867 doi:10.1098/rstb. 2010.0134

Rege JEO, Ayalew W, Getahun E, Hanotte O and Dessie T. 2006. DAGRIS (Domestic Animal Genetic Resources Information System). International Livestock Research Institute, Addis Ababa, Ethiopia. http://dagris.ilri.cgiar.org.

Southern regional State investment Bureau.2011. Available at: http://www.southinvest.gov.et
SPSS (Statistical Procedures for Social Sciences).2001 SPSS User's guide version 20.0. SPSS Institute Inc., Cary NC.

Takele Taye, 2005. On-Farm Phenotypic Characterization of Sheko Breed of Cattle and their Habitat in Bench Maji zone, Ethiopia. M.Sc Thesis. Alemaya University, Ethiopia

Thornton, 2006. Mapping climate vulnerability and poverty in Africa. Nairobi, Kenya: ILRI. http://www. dfid.gov.uk/research/mapping-climate. pdf.

Wondossen Ayalew and Tesfaye Feyisa.2017. Productive and reproductive performances of local cows in Guraghe zone, south west Ethiopia. Online Journal of Animal and Feed Research Volume 7 (5): 105-112.

Yifat D, Bahilibi W and Desie S.2012. Reproductive Performance of Boran Cows at Tatesa Cattle Breeding Center. Advances in Bio. Res. 6 (3): 101105.

Zewdu Wuletaw.2004. Indigenous Cattle Genetic Resources, Husbandry Practices and Breeding Objectives in Northwestern Ethiopia. M.Sc Thesis presented to the School of Graduate Studies of Haramaya University, Haramaya, Ethiopia.

Zinash, S., Aschaew, T., Alemu, Y. and Azage, T.2001. Status of livestock research and development in the highlands of Ethiopia. PP. 227-250. In: P.C. Wall (eds.).

\section{How to cite this article:}

Taju Hussein. 2018. Productive and Reproductive Performance of Indigenous Ethiopian Cow under Small Household Management in Dawro Zone, Southern Ethiopia. Int.J.Curr.Res.Aca.Rev. 6(5), 35-41.

doi: https://doi.org/10.20546/ijcrar.2018.605.007 